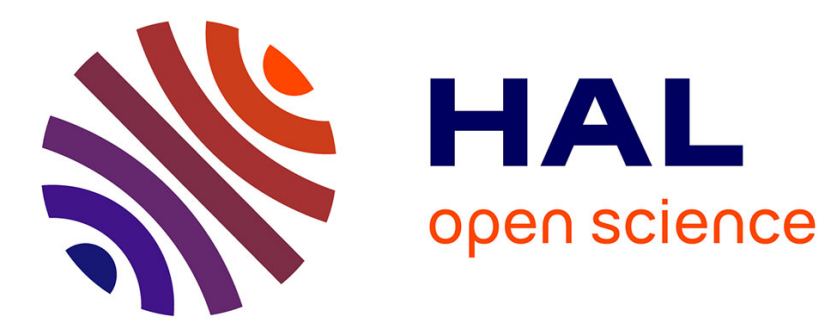

\title{
STRUCTURAL DIAGNOSTIC OF HIGH TEMPERATURE LIQUID PHASES BY 27Al NMR
}

\author{
D. Massiot, F. Taulelle, J.P. Coutures
}

\section{To cite this version:}

D. Massiot, F. Taulelle, J.P. Coutures. STRUCTURAL DIAGNOSTIC OF HIGH TEMPERATURE LIQUID PHASES BY 27Al NMR. Journal de Physique Colloques, 1990, 51 (C5), pp.C5-425-C5-431. 10.1051/jphyscol:1990551 . jpa-00230861

\section{HAL Id: jpa-00230861 https://hal.science/jpa-00230861}

Submitted on 1 Jan 1990

HAL is a multi-disciplinary open access archive for the deposit and dissemination of scientific research documents, whether they are published or not. The documents may come from teaching and research institutions in France or abroad, or from public or private research centers.
L'archive ouverte pluridisciplinaire HAL, est destinée au dépôt et à la diffusion de documents scientifiques de niveau recherche, publiés ou non, émanant des établissements d'enseignement et de recherche français ou étrangers, des laboratoires publics ou privés. 


\title{
STRUCTURAL DIAGNOSTIC OF HIGH TEMPERATURE LIQUID PHASES BY ${ }^{27}$ AI NMR
}

\author{
D. MASSIOT* *, F. TAULELLE* and J.P. COUTURES \\ Centre de Recherche sur la Physique des Hautes Températures, CNRS, UPR \\ 4212,45232 Orleans Cedex 2, France \\ - Laboratoire de Spectrochimie du Solide, CNRS, UA 320, université de \\ Paris VI, 75232 Paris Cedex 05, France \\ * Traitement de Materiaux par Laser de Puissance, CNRS, GS 911, \\ CALFEMAT, INSA, 69621 Villeurbanne cedex, France
}

Résumé - L'amélioration des procédés de soudage par plasma ou laser suppose une bonne connaissance des propriétés microscopiques du liquide constituant la zone fondue. Le développement de nouvelles sondes de résonance magnétique nucléaire permet d'atteindre cet objectif. L'analyse de la raie de résonance de ${ }^{27} \mathrm{Al}$ dans des oxydes liquides alumineux montre un régime d'échange rapide entre des coordinences quatre, cinq et six et une dépendance de la position de cette raie en fonction de la composition du liquide.

\begin{abstract}
Improvements of welding processes by plasma or laser require a good knowledge of the microscopic properties of the liquid associated to the melted area. The development of new high temperature NMR probes allows to reach such a goal. In the case of alumina bearing liquids, the analysis of the ${ }^{27} \mathrm{Al}$ resonance line shows a rapid exchange regime of $\mathrm{Al}$ in four, five or six fold coordination together with a dependence of the resonance line versus the liquid composition.
\end{abstract}

\section{1 - INTRODUCTION}

NMR is a well suited spectroscopy for the study of the liquid state and is widely used by organic chemists $\left({ }^{1} \mathrm{H}\right.$ and ${ }^{13} \mathrm{C}$ with or without cross polarization). Its development, in the high temperature area for non metallic materials, has been slowed down by technological problems : high magnetic fields $(4<\mathrm{Ho}<11 \mathrm{~T})$, interactions between the material under investigation with its holder imperatively a dielectric, time life of the radio-frequency components at temperature higher than $250^{\circ} \mathrm{C}$.

The first significant results have been obtained recently $/ 1-3 /$ on liquid silicates up to $1300^{\circ} \mathrm{C}$ or at higher temperature $\left(2100^{\circ} \mathrm{C}\right)$ on aluminum bearing oxides $/ 4 /$. Even if the signal intensity decreases with the temperature according to a Curie Law, the motional narrowing improves largely the dynamic of the signal. So if the sample under study and the RF components of the probe are thermally 
decoupled $(S / N=f(1 / T)$ it's easy to get a high signal to noise ratio and so representative data within a reasonable period of time.

We present here a new type of radio-frequency resonator with improved performances and obtained results on high temperature alumina bearing liquids.

\section{2 - EXPERIMENTAL}

The probe head, jointly patented with Bruker /5/ operates in axial configuration and is schematically shown Figure 1. Such a type of probe could be multinuclear or mononuclear and in this case optimized for a given nuclei $\left({ }^{27} \mathrm{Al}\right.$, $\left.{ }^{17} \mathrm{O} \ldots\right)$. In all cases the sample is aerodynamically levitated by a flowing gas (Argon, air, oxygen) at $1.5 \mathrm{lmm}^{-1}$. The convergent - divergent nozzle of the levitator structure is also the resonator of the radio-frequency circuitry for the mononuclear probe or is inserted in a modified VSP Bruker multinuclear probe. In this case, the levitator is made with BN. For the both probes the sample part and the RF circuitry are thermally decoupled. The typical experimental conditions are RF

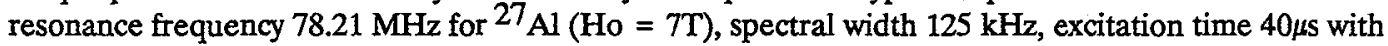
a dead time of $0.5 \mathrm{~s}$ between each pulse, acquired points 4.096, accumulated scans 130 .

The heating of the sample is provided by a CW CO 2 laser (MPB Technologies - Canada) with a power continuously variable between 20 and $120 \mathrm{~W}$.

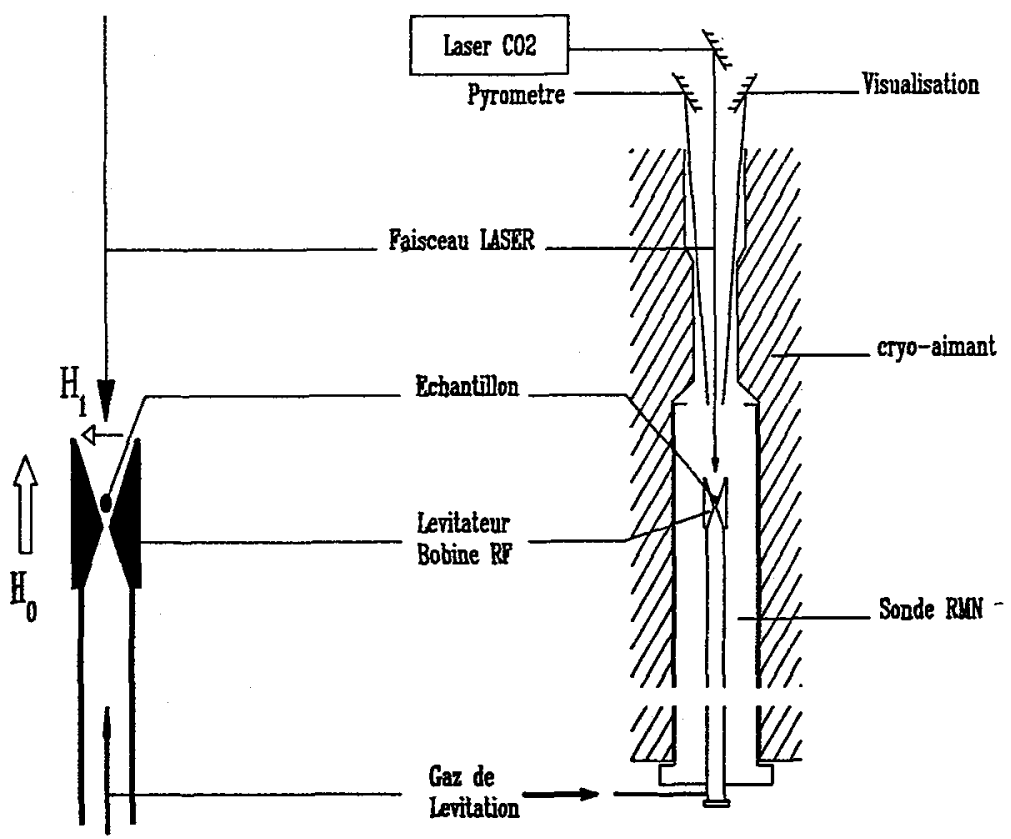

Fig.1 Set up of the aerodynamic high temperature proble 


\section{3 - RESULTS AND DISCUSSION}

As a first example Figure 2 shows the spectrum obtained when the $\mathrm{CO}_{2}$ laser beam $(P=60 \mathrm{~W})$ interacts with a porous silica - alimuna ceramic (mainly mullite) giving a partial melting. In this case the target is a cylinder of $10 \mathrm{~mm}$ diameter, $5 \mathrm{~mm}$ high and the melted volume around $3 \mathrm{~mm}^{3}$.

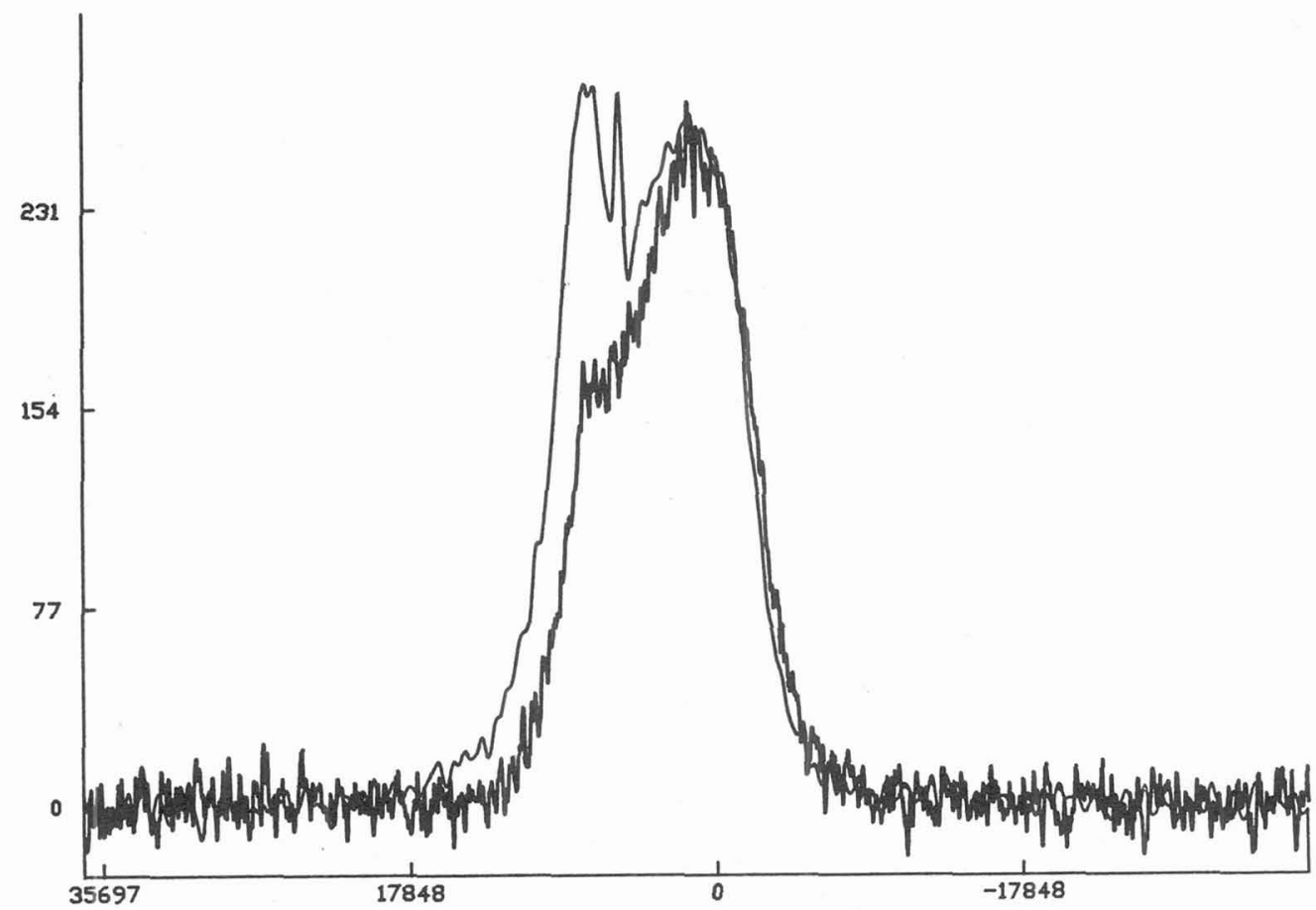

Fig. 2,27 Al resonance line of a silico-alumina ceramic

The darkness resonance line is obtained at room temperature under static conditions. This broad band $\left(-1 / 2-1 / 2\right.$ transition) is due to the strong quadrupolar coupling of ${ }^{27} \mathrm{Al}(\mathrm{S}=5 / 2)$ and also to the irradiation conditions. When the temperature increases (i.e the $\mathrm{CO}_{2}$ laser power) a partial melting occurs and a very fine peak is then observed. Its intensity growths up to the obtention of a thermal equilibrium regime (i.e melted volume) under the experimental conditions. The broad band is still present with a modified shape with a most finer component that we relate to the increase of the Al motional narrowing in the solid part with the temperature.

Figure 3 shows the ${ }^{27} \mathrm{Al}$ resonance line of pure $\mathrm{Al}_{2} \mathrm{O}_{3}$ and $\mathrm{Y}_{3} \mathrm{Al}_{5} \mathrm{O}_{12}$ liquids under air at a temperature slightly higher than their corresponding melting points. The resonance line exhibit a sharp profile of pure Lorentzian type. This fine line indicates, like in Figure 2, a fast exchange regime between the different possible coordination of $\mathrm{Al}$ in these liquids. The time scale $\left(\sim 10^{-9} \mathrm{~s}\right)$ is too long to resolve the contribution and so the population of the different sites. 


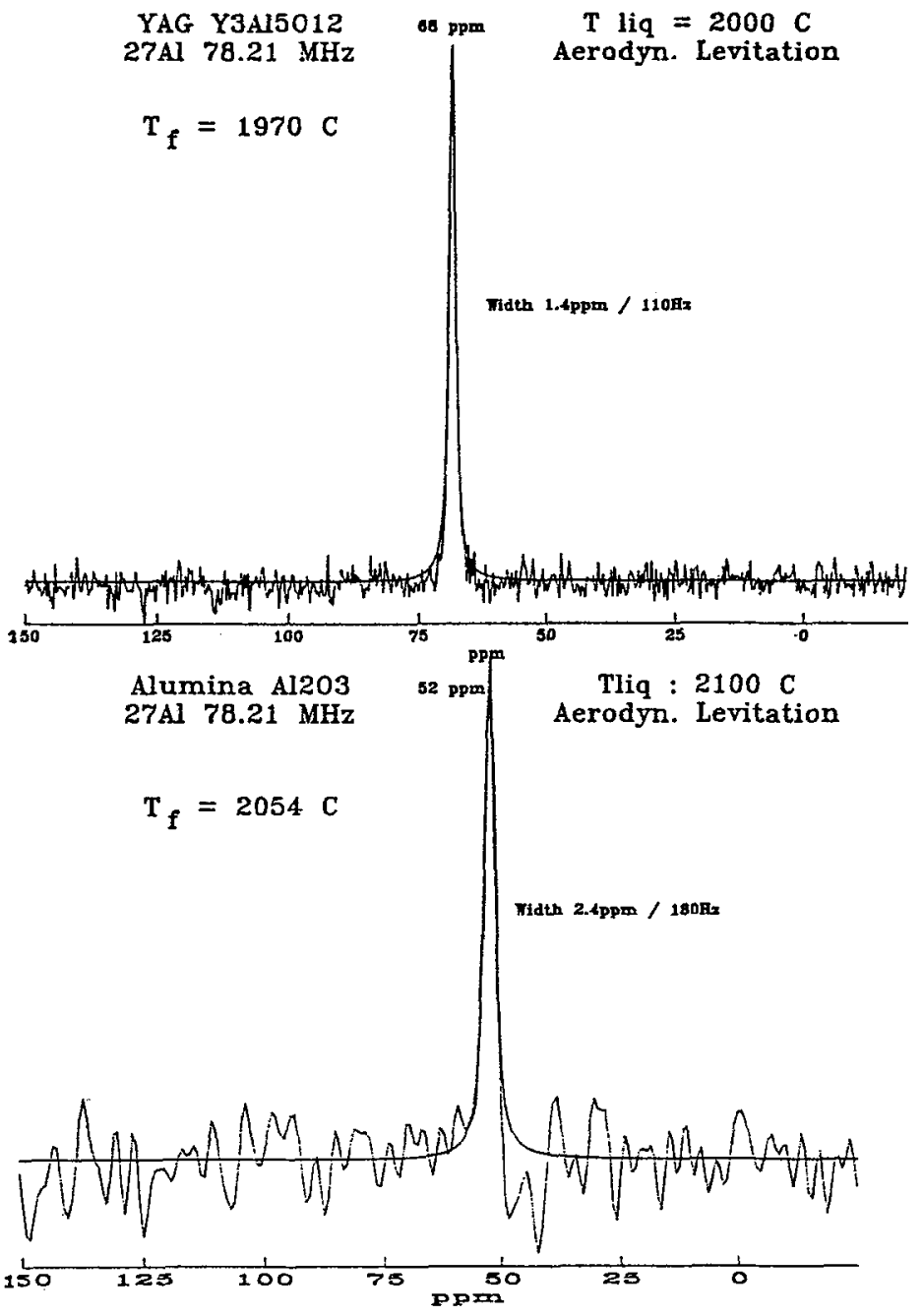

Fig. 3 : $27_{\mathrm{Al}}$ resonance line of a liquid $\mathrm{Al}_{2} \mathrm{O}_{3}$ and $\mathrm{Y}_{3} \mathrm{Al}_{5} \mathrm{O}_{12}$

The observed chemical shifts $\delta$ (reference ${ }^{27} \mathrm{Al}$ resonance line of $\mathrm{Al}\left(\mathrm{H}_{2} \mathrm{O}\right)_{6}{ }^{3+}$ in nitric aqueous solution at room temperature expressed in ppm are reported Table 1 . The position of the maximum of the resonance line is mainly related to the coordination of $\mathrm{Al}$ and the averaged $\mathrm{Al}-\mathrm{O}$ distances of the coordination polyhedra. We observe for $\mathrm{Al}$ in non silicated melts a range of $\delta$ varying from $52 \mathrm{ppm}$ $\left(\mathrm{Al}_{2} \mathrm{O}_{3}\right)$ up to $82 \mathrm{ppm}\left(0.37 \mathrm{Al}_{2} \mathrm{O}_{3}-0.63 \mathrm{CaO}\right.$ liquid). The range of chemical shift is more larger than for the solids (10 ppm for fourfold coordinated $-75 \pm 5 \mathrm{ppm} ; 10 \mathrm{ppm}$ for $\mathrm{Al}$ in octahedral coordination $5 \pm 5 \mathrm{ppm}$ ). Some of the results obtained are given Table 1 where for each compound the data on the corresponding solid are shown. These data have been obtained on crystallized samples by the Bruker MAS (Magic Angle Spinning) probe operated at a frequency of rotation of $15 \mathrm{kHz}$. 


\section{4 - FUTURE AND CONCLUSION}

We have reported here new experimental results obtained during the last four months and focused only on $\mathrm{Al}$ atoms. These experiments are in progress and the final set up which is planned to be in working conditions end of 1990 is shown Figure 4. This set up must allow to operate with a better temperature homogeneity by the use of two lasers to heat simultaneously the upper and the lower area of the target. In this case the NMR spectrometry itself could be used to carry out temperature measurements without the necessity of the knowledge of the emissivity.

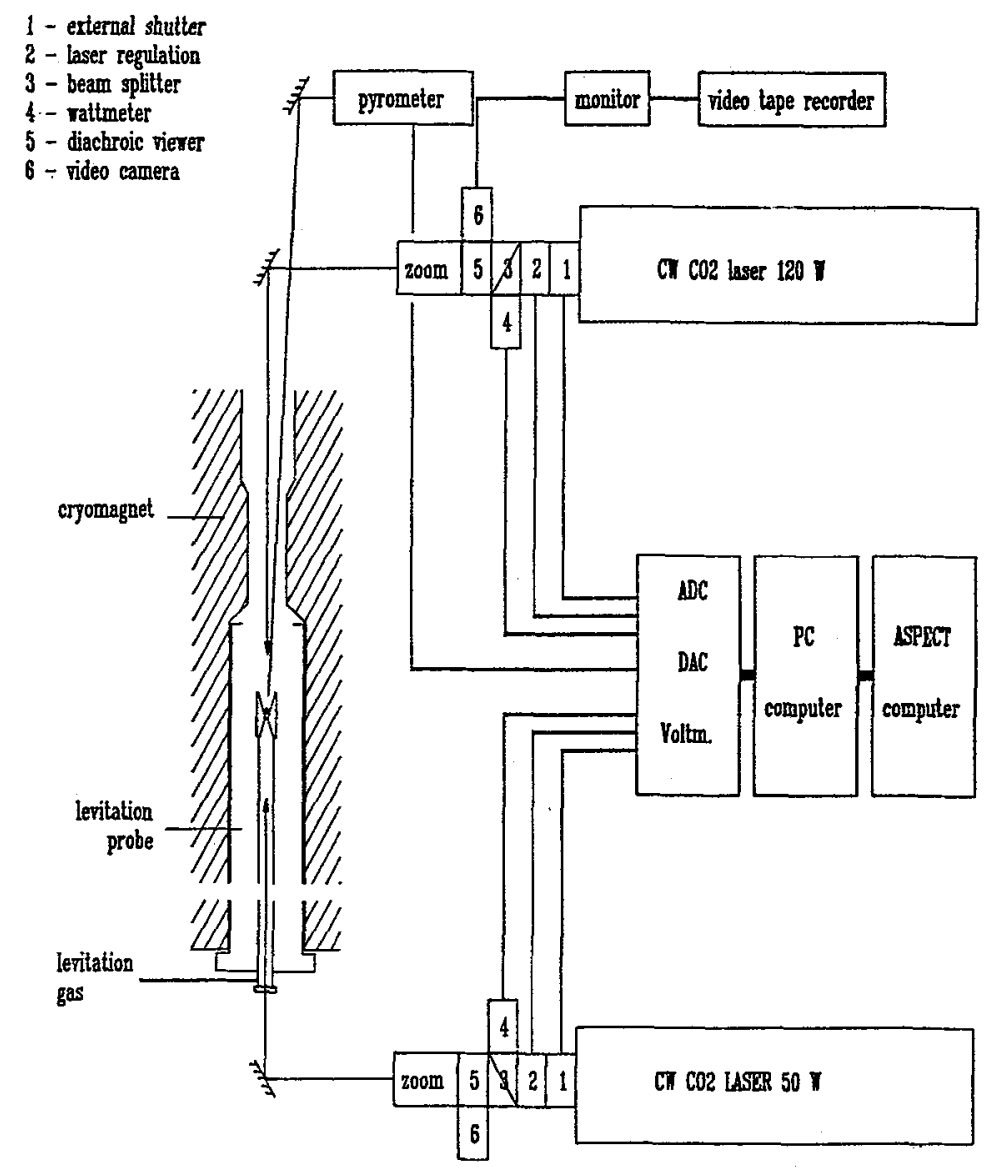

Fig.4 set up of the improved high temperature NMR spectrometer

A specific, optimized ${ }^{17} \mathrm{O}$ probe is planned to be in operation at the same time and so information on oxygen could be available. Even if $17 \mathrm{O}$ has a very low natural abundance $(0.036 \%)$, very interesting results have been obtained on low viscosity liquids $\left(\mathrm{K}_{2} \mathrm{SO}_{4}-\mathrm{Na} \mathrm{NO}_{3}\right.$ mixtures) indicating that liquids having an atomic concentration of ${ }^{17} \mathrm{O}$ in the percent range could be studied. Very recently ${ }^{17} \mathrm{O}$ MAS-NMR results on solid oxides have been obtained without any enrichment $/ 7 /$. As stated previously we have focused this paper only on the study of liquid which are isotropic medium 
TABLE I $: 27_{A 1}$ MMR results on alumina bearing material

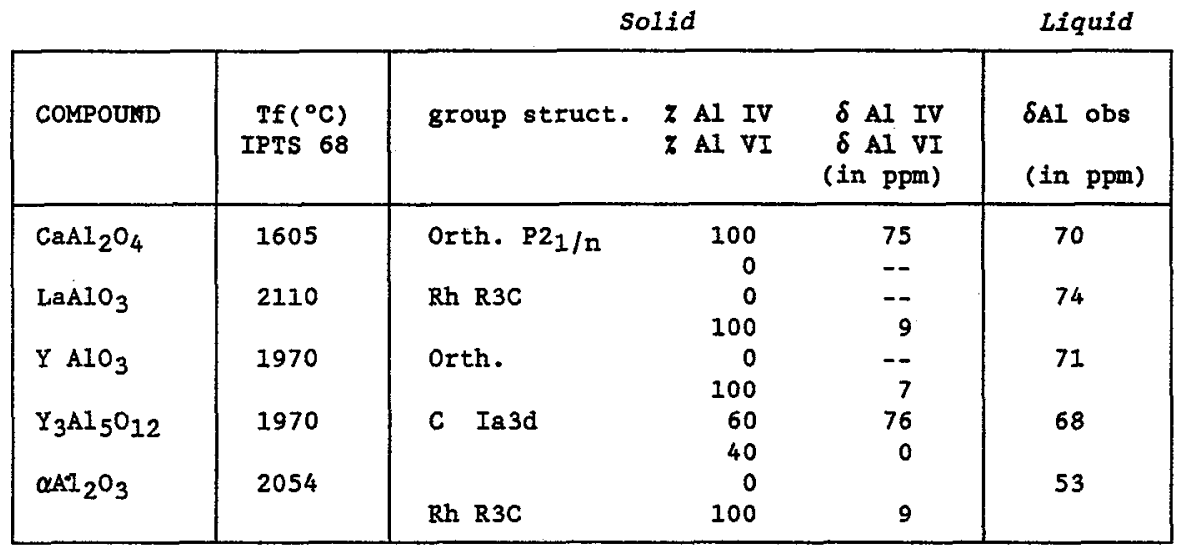

For liquid $\mathrm{Al}_{2} \mathrm{O}_{3}$ and yttrium aluminium garnet (YAG) the full width at half maximum of the resonance line is respectively 2.4 and $1.4 \mathrm{ppm}$. Such a parameter is related to the statistic disorder of configuration of the site under examination plus in the case of high temperature experiments a contribution to the temperature gradient in the sample. The effect of the atmosphere (oxygen potential of the flowing gas) is under examination and shows a complex behavior. Even if the thermal conductivity of argon and oxygen are quite different leading to a possible variation of the sample temperature an effect of the oxygen potential of the flowing gas on the melt is observed. This is particularly clear with liquid YAG and is coherent with previous results on the observation by EPR of paramagnetic defects of $\mathrm{Al}-\mathrm{O}-\mathrm{O}^{\circ}$ type on glassy YAG only when the corresponding liquid is melted under air or oxygen /6/. The FWHM could also be dependent of the oxygen partial pressure of the levitation gas ( $\mathrm{Al}_{2} \mathrm{O}_{3}$ Argon $100 \mathrm{~Hz}$ oxygen $72 \mathrm{~Hz}$; YAlO 3 Argon $70 \mathrm{~Hz}$ - oxygen $124 \mathrm{~Hz}$ ).

The sensivity of this approach to the liquid composition was checked on commercially available electrically melted ceramics (SEPR, Jargal Trade Mark). The results are reported Table 2. In a first analysis we could say that the population of octahedral $\mathrm{Al}^{3+}$ in these liquids decreases versus their $\mathrm{Al}_{2} \mathrm{O}_{3}$ molar content.

TABLE 2 : Chemical of ${ }^{27}$ Al in Jargal family liquids

\begin{tabular}{|c|c|c|c|c|}
\hline Jargal Name & $\begin{array}{l}\text { Compos } \\
\mathrm{Al}_{2} \mathrm{O}_{3}\end{array}$ & $\begin{array}{l}\text { ition } \\
\mathrm{SiO}_{2}\end{array}$ & $\begin{array}{l}(\text { mole } z) \\
\mathrm{Na}_{2} \mathrm{O} \\
\mathrm{MgO}\end{array}$ & $\delta$ AI obs ppm \\
\hline$M$ & 95.6 & 0.54 & 3.8 & 56.4 \\
\hline H & 93.7 & 0.14 & 6.1 & 62.8 \\
\hline N X 5312 & 86.9 & 0.36 & 4.7 & 64.7 \\
\hline
\end{tabular}


nevertheless the use of selective and non selective pulse sequences allows to study biphasic mixtures (liq + sol). Direct information on the motional narrowing of the nucleus under investigation could also be obtained by $T_{1}$ measurements. Special probes working under a known VT allows also to carry out measurements on autodiffusion coefficients.

\section{ACKNOWLEDGMENTS}

Authors greatly acknowledge for fruitful discussions on the Al coordination in liquids Professor P. MAC MLLAN (Arizona State University), Dr. A. DOUY (CRPHT) which provide powders of $\mathrm{LaAlO}_{3}, \mathrm{YAlO}_{3}$ and $\mathrm{Y}_{3} \mathrm{Al}_{5} \mathrm{O}_{12}$ chemically homogeneous and Dr. J. RECASSENS (SEPR Le Pontet) for the Jargal Ceramics.

The financial support of CNRS (Chemistry Department ; PIRMAT), Région Centre, DRET, CNES and University of Orléans are greatly acknowledged together with the Bruker Company particularly Drs C. BREVARD and D. MULLER.

\section{REFERENCES}

11/ Stebbins, J.F., Murdoch, J.B., Schneider, E., Carmichael, S.E. and Pines, A., Nature 314 (1985) 250.

12/ Stebbins, J.F., Scneider, E., Murdoch, J.B., Pines, A. and Carmichael, S.E., Rev. Scient. Instr. $\underline{57}$ (1986) 39.

13/ Shimokawa, S., Mackawa, H., Yamada, E., Mackawa, T., Nakamma, Y. and Yokokawa, T., Chem. Lett. (1990) 617.

14/ Coutures, J.P., Massiot, D., Bessada, C., Echegut P., Rifflet, J.C. and Taulelle, F., C.R. Acad Sci. Paris 310 II (1990) 1041.

15/ Brevard, C; Coutures, J.P., Massiot, D., Rifflet, J.C. and Taulelle F., French Patent FR 8802741.

16/ Badets, M.C., Bessada, C., Simon, P., Billard, D., Douy, A., Massiot, D., Rifflet, J.C., Taulelle, F. and Coutures J.P., ESA SP-295 (1990) 511.

77/ Bastow, T.J and Stuart, S.N., Chemical Physics 144 (1990). 